\title{
Effects of Polyethylene Terephthalate and Steel Fibre in Hybrid Fibre Reinforced Concrete
}

\author{
D. Maruthachalam*, S. C. Boobalan and V. Muthukrishnan \\ Sri Krishna College of Engineering and Technology, Coimbatore - 641008, Tamil Nadu, India; \\ dmaruthachalam@gmail.com, boobalanpras@gmail.com,krishnan.muthu30@gmail.com
}

\begin{abstract}
Objectives: Hybrid Fibre Concrete (HyFRC) which make use of Polyethylene Terephthalate (PET) and Steel Fibre (SF) is considered in this research. HyFRC mechanical properties such as splitting tensile strength, compressive strength and flexural strength will be studied. Methods/Findings: By using IS 10262-2009 code, M40 grade HyFRC was designed with steel and PET fibre were included upto $0.5 \%$ by volume of concrete. Experimental investigation showed that superior performance was achieved in HyFRC when using the hybrid fibre form instead of single fibre concretes. This investigation concluded that concrete containing PET fibres of $0.12 \%$ and steel fibres of $0.38 \%$ grouping as the best combination to be engaged in HyFRC for mechanical properties such as splitting tensile strength, compressive strength and flexural strength. Application/Improvements: Optimum proportion of fibres in HyFRC was identified from the mechanical properties results. Thus the crack pattern and ductility behaviour will be studied by using beam column specimens.
\end{abstract}

Keywords: Polyethylene, Steel Fibre

\section{Introduction}

Concrete is quite a fragile composite material. In order to conquer the weakness, metallic or polymeric kinds of fibres have been considered. In $^{1}$ reality, sufficient mechanical properties, tensile and strain capacity cannot be achieved by single fibre. As a result, combination of two or more fibres was introduced and had been made as HyFRC containing dispersed randomly oriented fibres $^{2}$. Hybrid fibre combination of $0.5 \%$ volume fraction such as carbon, steel, polypropylene fibres and polyester were introduced and mechanical properties were compared with the normal concrete mix. $\operatorname{In}^{3}$ investigated the mechanical properties such as splitting tensile strength, compressive strength and flexural strength of high strength concrete with non-metallic polypropylene and metallic steel fibres, glass fibres and polyester at $0.5 \%$ volume fraction, outcome showed that non-metallic fibres slow down the formation of micro cracks whereas metallic steel fibres contributed energy absorbing mechanism and hybrid combination showed improvement in concrete properties and overall cost of production of concrete was reduced ${ }^{4}$.

In $^{5}$ investigated to improve the crack resistance and tensile property with recycled PET fibres in concrete. Compressive strength and toughness of concrete was enhanced by immersion of steel fibres. Owing to the PET fibres superior ductility, fineness plastic cracks were controlled. In this research, hybrid fibres were mixed with concrete to enhance the splitting tensile strength, compressive strength and flexural strength. This investigation

${ }^{*}$ Author for correspondence 
reports the strength properties of HyFRC compared with the controlled concrete mix.

\section{Materials and Experimental Work}

\subsection{Materials}

All the concrete mixes were prepared with Portland Pozzolona Cement, fine aggregate of river sand with 2.65 specific gravity and conforming to BIS 383 (1970) and coarse aggregate with 2.60 specific gravity and aggregate retaining on $12.5 \mathrm{~mm}$ sieve and passing through $20 \mathrm{~mm}$ sieve $^{6}$. Specimens were casted along with workability enhancing admixture of Superplasticizer (Conplast SP 430) with 1.22 specific gravity, chloride free admixture. Recycled PET and steel fibres physical and mechanical properties are listed in Table 1.

\subsection{Concrete Mix Proportioning}

To acquire the target strength of $40 \mathrm{MPa}$ at 28 days concrete mix was prepared accordingly. To maintain the

Table 1. Mechanical and Physical Properties of Steel and PET fibres

\begin{tabular}{|c|c|c|}
\hline Property Description & Steel fibre & Recycled PET \\
\hline Specific Gravity & 7.8 & 1.35 \\
\hline Tensile Strength & 1700 & 970 \\
\hline Length $(\mathrm{mm})$ & 50 & 38 \\
\hline Diameter $(\mathrm{mm})$ & 0.5 & 0.025 \\
\hline Aspect Ratio $(\mathrm{l} / \mathrm{d})$ & 100 & 1520 \\
\hline
\end{tabular}

Table 2. Concrete Mix Proportions

\begin{tabular}{|c|c|c|c|c|}
\hline $\begin{array}{c}\text { Cement } \mathbf{k g} \\
/ \mathbf{m}^{3}\end{array}$ & $\begin{array}{c}\text { FA } \\
\mathbf{~ g ~} / \mathbf{m}^{3}\end{array}$ & $\mathbf{C A ~ k g / \mathbf { m } ^ { 3 }}$ & $\begin{array}{c}\text { Water } \\
\mathbf{l i t} / \mathbf{m}^{3}\end{array}$ & SP lit $/ \mathbf{m}^{3}$ \\
\hline 394.32 & 717.288 & 1152.58 & 157.728 & 3.945 \\
\hline
\end{tabular}

Table 3. Dosage of Steel fibre and Recycled PET fibre Combinations in this study

\begin{tabular}{|c|c|c|c|c|}
\hline \multirow{2}{*}{ Concrete Mix } & $\mathbf{V}_{\mathrm{f}}$ & $\mathbf{V}_{\mathrm{f}}$ & \multicolumn{2}{|c|}{$\begin{array}{c}\text { Fibre Dosage } \\
\mathbf{k g} / \mathbf{m}^{3}\end{array}$} \\
\cline { 2 - 5 } & SF \% & RPET \% & Steel & RPET \\
\hline SFRC & 0.5 & - & 39 & - \\
\hline HyFRC1 & 0.12 & 0.38 & 9.36 & 5.13 \\
\hline HyFRC2 & 0.25 & 0.25 & 19.50 & 3.38 \\
\hline HyFRC3 & 0.38 & 0.12 & 29.64 & 1.62 \\
\hline PERC & - & 0.5 & - & 6.75 \\
\hline
\end{tabular}


workability ranges from 75-125 mm, Superplasticizer dosage was varied. Detailed concrete mix proportion quantities of this investigation study ${ }^{7}$ and volume fractions of steel fibres and recycled PET fibres existed were presented in Tables 2-3 respectively.

\subsection{Concrete Preparation and Casting Details}

Steel fibre and recycled PET fibres at $0.5 \%$ by volume of concrete were mixed to each concrete mix of hybrid fibre reinforced concrete. Superplasticizer was mixed with $1 \%$ by weight of cement in the fibre reinforced concrete for improving the workability. Standard set of specimen sizes such as cubes, cylinder and prism were casted for testing the 28 days properties such as Splitting tensile strength,
Compressive strength and Flexural strength of the concrete.

\section{Results and Discussion}

\subsection{Workability Test}

Workability measurement, Slump value of various concrete mixes is listed in Table 4. Slump ranges from $75 \mathrm{~mm}$ to $125 \mathrm{~mm}$ resulted from the prepared concrete mix.

\subsection{Compressive Strength Test Results}

For measuring compressive strength of fibre concrete specimens were casted with M40 grade of concrete and size of $150 \mathrm{~mm} \times 150 \mathrm{~mm} \times 150 \mathrm{~mm}$ cubes $^{8}$. Concrete was ready with $0.5 \%$ SF, $0.12 \% \mathrm{RPET} \& 0.38 \% \mathrm{SF}, 0.25 \% \mathrm{RPET}$

Table 4. Workability Test Results

\begin{tabular}{|c|c|}
\hline Mix & Slump (mm) \\
\hline SFRC & 108 \\
\hline HyFRC1 & 92 \\
\hline HyFRC2 & 83 \\
\hline HyFRC3 & 78 \\
\hline PFRC & 72 \\
\hline
\end{tabular}

Table 5. Compressive Strength Results

\begin{tabular}{|c|c|c|c|c|}
\hline Concrete Mix & Spec. 1 & Spec. 2 & Spec. 3 & $\begin{array}{c}\text { Avg. Compressive } \\
\text { Strength (MPa) }\end{array}$ \\
\hline SFRC & 47.00 & 49.20 & 48.10 & 48.10 \\
\hline HyFRC1 & 49.34 & 49.18 & 50.20 & 49.57 \\
\hline HyFRC2 & 47.00 & 46.28 & 43.00 & 45.43 \\
\hline HyFRC3 & 40.20 & 39.43 & 40.56 & 40.06 \\
\hline PERC & 38.02 & 36.70 & 37.22 & 37.31 \\
\hline
\end{tabular}


\& $0.25 \%$ SF and $0.38 \%$ RPET \& $0.12 \%$ SF. Specimens were allowed for 28 days of curing after demoulding of specimens from 24 hours of casting. Results of compressive strength values are given in Table 5 . Compressive strength value of fibre concrete was measured by $2000 \mathrm{kN}$ capacity of compressive testing machine. $\mathrm{In}^{9}$ each mix of concrete, three cubes were casted and their average value was reported as final value.

\subsection{Splitting Tensile Strength Test Results}

For measuring splitting tensile strength of fibre concrete specimens were casted with a size of $300 \mathrm{~mm}$ height and $150 \mathrm{~mm}$ diameter $^{8}$. Specimens were allowed for 28 days of curing after demoulding of specimens from 24 hours of casting. Results of splitting tensile strength values are given in Table 6. Splitting tensile strength values of fibre concrete was measured by $2000 \mathrm{kN}$ capacity of compressive testing machine in that specimens placed horizontally 9

\subsection{Flexural Strength Test Results}

For measuring flexural strength of fibre concrete specimens were casted with a size of $100 \mathrm{~mm} \times 100 \mathrm{~mm}$ x $500 \mathrm{~mm}^{8}$. Specimens were allowed for 28 days of curing after demoulding of specimens from 24 hours of casting. Results of flexural strength values are given in Table

Table 6. Splitting Tensile Strength Results

\begin{tabular}{|c|c|c|c|c|}
\hline Concrete Mix & Spec. 1 & Spec. 2 & Spec. 3 & $\begin{array}{c}\text { Avg. Splitting Tensile } \\
\text { Strength (MPa) }\end{array}$ \\
\hline SFRC & 4.34 & 3.98 & 4.10 & 4.10 \\
\hline HyFRC1 & 4.16 & 4.28 & 4.17 & 4.17 \\
\hline HyFRC2 & 4.16 & 4.08 & 3.99 & 4.00 \\
\hline HyFRC3 & 3.87 & 3.72 & 3.90 & 3.80 \\
\hline PERC & 3.56 & 3.80 & 3.39 & 3.39 \\
\hline
\end{tabular}

Table 7. Flexural Strength Results

\begin{tabular}{|c|c|c|c|c|}
\hline $\begin{array}{c}\text { Concrete } \\
\text { Mix }\end{array}$ & Spec. 1 & Spec. 2 & Spec. 3 & $\begin{array}{c}\text { Avg. Flexural } \\
\text { Strength (MPa) }\end{array}$ \\
\hline SFRC & 5.40 & 5.39 & 5.06 & 5.28 \\
\hline HyFRC1 & 5.32 & 5.41 & 5.30 & 5.34 \\
\hline HyFRC2 & 4.80 & 5.02 & 4.84 & 4.84 \\
\hline HyFRC3 & 4.58 & 4.42 & 4.70 & 4.57 \\
\hline PERC & 4.08 & 4.21 & 4.36 & 4.22 \\
\hline
\end{tabular}


7. Flexural strength value of concrete was measured by using $100 \mathrm{kN}$ capacity Flexural Testing Machine?

\section{Conclusion}

In this research work, strength and properties of Hybrid Fibre (RPET and Steel Fibre) Concrete was evaluated. The test results indicated that concrete with enhanced strength was achieved at minimum fibre volume portion. The mechanical properties such as splitting tensile strength, compressive strength and flexural strength outcome obviously revealed that higher strength was achieved with the fibre volume fraction in combination of steel fibre with $0.38 \%$ and RPET fibre with $0.12 \%$.

\section{References}

1. Qian CX, Stroeven P. Development of hybrid polypropylene steel fibre reinforced concrete. Cement and Concrete Research. 2000; 30(1):63-9.bhttps://doi.org/10.1016/S00088846(99)00202-1.

2. Yao W, Li J, Wu K. Mechanical properties of hybrid fibre reinforced concrete at low fibre volume fraction. Cement and Concrete Research. 2007; 37:23-30.
3. Sivakumar A, Santhanam M. Mechanical properties of high strength concrete reinforced with metallic and non-metallic fibres. Cement and Concrete Composites. 2007; 29(8):603-8. nhttps://doi.org/10.1016/j.cemconcomp.2007.03.006 .

4. Won JP, Jang C, Lee SW, Lee SJ, Kim HY. Long term performance of recycled PET fibre reinforced cement composites. Construction and Building Materials. 2010; 24(5):660-5. https://doi.org/10.1016/j.conbuildmat.2009.11.003.

5. Song S, Hwang S. Mechanical properties of high strength steel fibre reinforced concrete. Construction and Building Materials. 2004; 18(19):669-73.nhttps://doi.org/10.1016/j. conbuildmat.2004.04.027.

6. BIS 383. Specification for Coarse and Fine Aggregates from Natural Source for Concrete. Bureau of Indian Standards, India. 1970; p. 1-24.

7. BIS 10262. Recommended Guidelines for Concrete Mix Design. Bureau of Indian Standards, India. 2009; p. $1-21$.

8. BIS 516. Methods of Tests for Strength of Concrete. Bureau of Indian Standards, India. 1959; p. 1-30.

9. Hsie M, Tu C, Song PS. Mechanical properties of polypropylene hybrid fibre reinforced concrete. Material Science and Engineering. 2008; 494(1-2):153-7. https://doi. org/10.1016/j.msea.2008.05.037. 